\title{
AIRWAY MANAGEMENT WITH DIRECT LARYNGOSCOPY IN A CHILD WITH GOLDENHAR SYNDROME
}

\author{
Bibiana Vitković and Morena Milić \\ Clinical Department of Anesthesiology and Intensive Care Medicine, Dubrava University Hospital, Zagreb, \\ Croatia
}

\begin{abstract}
SUMMARY - Goldenhar syndrome, also known as oculoauriculovertebral dysplasia, is a rare congenital condition characterized by facial, cranial, vertebral, ocular, auricular and cardiac abnormalities. This syndrome is associated with hemifacial microsomia due to inadequate growth of the mandible and vertebral anomaly of the cervical part of the spine. For anesthesiologists, airway management is of great interest because of facial and oral abnormalities such as mandibular hypoplasia and limitation of neck movement. Considering different conditions of Goldenhar syndrome, every patient should be preoperatively evaluated in order to make the plan for the anticipated difficult airway management. We report a case of a 2.5 -year-old boy undergoing palatoplasty, who required general anesthesia and orotracheal intubation. Our decision to intubate with direct laryngoscopy and with slight external pressure on the larynx proved successful.
\end{abstract}

Key Words: Airway Management; Airway Obstruction; Goldenhar Syndrome; Anesthesia; Palatoplasty

\section{Introduction}

Goldenhar syndrome was first described in 1952. The syndrome is sometimes hereditary, autosomal recessive or dominant transmitted, but may also occur randomly. The pathogenesis can be explained with inadequate vascular supply of the first two brachial branches, resulting in malformation of structures in fetal development. The incidence is estimated between $1 / 3000$ and $1 / 5000$ live births, and the male/ female ratio is $2: 1$, with male predominance.

Goldenhar syndrome is also known as oculoauriculovertebral dysplasia or hemifacial microsomia. The syndrome include the following conditions: hemifacial microsomia, vertebral anomalies of different size and shape, microtia, preauricular skin tags, central nervous system malformations, cardiac malformation,

Correspondence to: Bibiana Vitkovic, $M D$, Clinical Department of Anesthesiology and Intensive Care Medicine, Dubrava University Hospital, Avenija Gojka Šuška 6, HR-10000 Zagreb, Croatia E-mail: bibianavit@hotmail.com

Received February 27, 2015, accepted: September 9, 2015 epibulbar dermoid cyst, and unilateral maxillary hypoplasia. Eyelid colobomas, microphthalmia, genitourinary anomalies and deafness may also be included. Cleft palate can be found in $10 \%$ of these children. The consequence of unilateral mandibular hypoplasia and vertebral anomalies are limitations of neck movements and changes in the airway anatomy. Accordingly, anesthesiologist must be aware of difficult ventilation and difficult intubation ${ }^{1}$.

We describe successful orotracheal intubation in a 2.5-year-old child with Goldenhar syndrome, scheduled for plastic reconstruction of the cleft palate. Despite predicted difficult airway management, we successfully intubated the child using direct laryngoscopy.

\section{Case Report}

A 2.5-year-old boy, body weight $10 \mathrm{~kg}$, was presented for palatoplasty. He was delivered as a premature due to fetal suffering, birth weight $1420 \mathrm{~g}$, Apgar score 7/7. Immediately after birth, oxygen saturation was low, consequently nasotracheal intubation was 
performed. After caffeine citrate therapy in intensive care unit (ICU), the child was extubated and stayed in the hospital for 58 days. The boy was diagnosed with Goldenhar syndrome.

Physical examination performed preoperatively revealed micrognathia and hypoplasia of the right side of the mandible; furthermore, the coronoid process and the mandibular condyle did not exist; complete clefts of the soft and the last third of the hard palate were visible. Ears were underdeveloped and there were two bilateral preauricular tags. Additionally, there was a coloboma, a minor defect on the medial half of the right upper eyelid.

Cervical spine $\mathrm{x}$-ray showed hemivertebra $\mathrm{C} 7$ and megastransversus C7 and Th 1 . Consequently, the examination showed torticollis with concavity on the right side and flat physiological lordosis.

$\mathrm{X}$-ray of thoracic organs, abdomen ultrasound and brain ultrasound were normal. Ultrasound of the heart revealed foramen ovale apertum and small tricuspidal regurgitation; electrocardiography showed sinus rhythm of $150 / \mathrm{min}$; the cardiologist confirmed good heart performance.

Laboratory findings were as follows: hemoglobin $12 \mathrm{~g} / \mathrm{dL}$, hematocrit 33\%, and leukocyte count $8.5 \times 10^{9} / \mathrm{L}$. There were no known allergies and no history of previous surgery. According to airway assessment, since the child was not cooperative at the moment of examination, the Mallampati score was not possible to evaluate ${ }^{2}$. Movements of the neck were limited. He was classified as the American Society of Anesthesiologists (ASA II) physical status.

Premedication was administered $30 \mathrm{~min}$ before surgery: $1 \mathrm{mg}$ midazolam and $0.15 \mathrm{mg}$ atropine, intramuscularly. Anesthesia was induced by using $100 \%$ oxygen with sevoflurane which was slowly increased. Additionally, when ventilation was satisfactory, thiopental $40 \mathrm{mg}$, fentanyl $0.03 \mathrm{mg}$ and vecuronium 1 $\mathrm{mg}$ were administrated to deep anesthesia and to allow best condition for laryngoscopy. After 3 minutes of uneventful ventilation, laryngoscope (Macintosh blade number one) was slowly introduced, the tip of the epiglottis was shown. Slight external pressure on the larynx was performed by anesthetic technician, visibility of aditus was improved, and arytenoids were visualized. Flexible tube number 3.5 I.D. with stylet was placed. The position of the orotracheal tube was confirmed by auscultation and capnography. After thoughtful fixation, a small amount of throat pack was put in the oropharynx as additional fixation of the endotracheal tube and capture for saliva and blood.

Electrocardiography, peripheral oxygen saturation, noninvasive blood pressure, body temperature and capnography were monitored. Stethoscope was attached with a patch on the left side of the thorax. The intravenous cannula was inserted on the left foot.

At the beginning of surgical procedure, the operation field was infiltrated by the surgeon with a mixture of lidocaine and adrenaline, and correct position of the orotracheal tube was confirmed once again after introducing the mouth gag. The anesthesia was maintained with sevoflurane 2 vol \%. During the surgery, the patient was hemodynamically stable, peripheral oxygenation was $100 \%$, and body temperature was normal; the patient received prophylactic cefuroxime $30 \mathrm{mg} / \mathrm{kg}$ and dexamethasone $4 \mathrm{mg}$. Palatoplasty, frenectomy and removal of preauricular tags were performed. At the end of 60-minute operation, the boy started breathing spontaneously and was awake soon. Postoperative period was uneventful and the patient was discharged from the hospital after 6 days.

\section{Discussion}

The presence of cleft palate without cleft lip in a newborn is often correlated with other birth defects and syndromes ${ }^{3}$. The best known syndromes correlating with isolated cleft palate are Pierre Robin sequence, Treacher Collins syndrome, Goldenhar syndrome, and velocardiofacial syndrome.

Children born with congenital disorders deserve special attention of anesthesiologist when airway management and general anesthesia are required. Every patient should be carefully examined. It is important to notice morphology of the head and neck, micrognathia, jaw movements, dentition, and possible dysmorphic features ${ }^{2}$. After preoperative examination, anesthesiologists should prepare the plan for tracheal intubation, i.e. difficult airway management, and consider using special devices. Orotracheal intubation (flexible tube with cuff) is the safest approach to protect airway in plastic reconstruction of cleft palate.

If the risk of intubation is greater than the benefit of the procedure, anesthesiologist, surgeon and par- 
ents have to decide whether to abandon or proceed with the surgical procedure.

The standard technique for expected difficult intubation is awake intubation with flexible fiberoptic bronchoscope (FOB) using topical anesthesia if the patient is cooperative. The children cannot be cooperative and sedation or general anesthesia before fiberoptic intubation is necessary. FOB is expensive and easily damaged, especially those of small pediatric diameter; the usage of FOB needs special education and training. Recent studies have shown that fiberoptic intubation via laryngeal mask airway (LMA) is acceptable technique for a child with Goldenhar syndrome ${ }^{4}$. Comparison of $\mathrm{FOB}$ intubation and intubation with rigid bronchoscope was recently made, with good results for both techniques ${ }^{5}$. There is also a report on successful intubation with video laryngoscope in a child with Goldenhar syndrome ${ }^{6}$. According to the literature, LMA is successfully used in children with Goldenhar syndrome, especially for ophthalmic surgery.

Pediatric anesthesiologists should be familiar with intubation with stylet under direct laryngoscopy when laryngeal visualization is not satisfactory. In this case, different blades such as Mackintosh, Miller and $\mathrm{McC}$ oy should be available. Gooden et al. report on a 21-month-old child with Goldenhar syndrome where nasal and oral FOB intubation was not successful and blind intubation under direct laryngoscopy was performed successfully ${ }^{7}$. In one study, intubation of all 17 children with Goldenhar syndrome who required surgery proved uneventful ${ }^{8}$.

According to the technique of anesthesia, standard approach to a child with anticipated difficult airway is inhalation induction with sevoflurane, which ensures adequate depth of anesthesia before airway instrumentation and spontaneous ventilation. Muscle relaxant should be avoided until the airway is secured. In our case, muscle relaxant was used to ensure better visualization of the glottis. His past experience with intubation was successful and was not too long before. In some similar syndromes like Treacher Collins, the airway anatomy changes with growth and history of past intubation has no relevance for the current case. Our plan B, in case of impossibility to intubate, was to ventilate the child and awake him.

After palatal surgery, children should be monitored as there is the possibility of postoperative apnea, bleeding or swelling ${ }^{3}$.

\section{Conclusion}

The only wise approach to the management of the anticipated difficult airway in a child with Goldenhar syndrome is clear strategy that provides satisfactory oxygenation, ventilation and good surgical visualization. Orotracheal intubation with direct laryngoscopy and slight external pressure on the larynx was a good choice in this case. We decided to administer muscle relaxant to facilitate intubation, only after confirmation of adequate ventilation.

An individual management plan should be selected considering the special conditions and different airway anatomy of every child with Goldenhar syndrome. One should not forget that anesthesiologist experienced in difficult pediatric airway management should be consulted when approaching children with a rare syndrome.

\section{References}

1. Butler MG, Hayes BG, Hathaway MM, Begleiter ML. Specific genetic diseases at risk for sedation/anesthesia complications. Anesth Analg. 2000;91(4):837-55.

2. Cardwell M, Walker RWM. Management of the difficult paediatric airway. $\mathrm{Br} \mathrm{J}$ Anaesth CEPD Reviews. 2003;3(6):167-70. doi:10.1093/bjacepd/mkg167

3. Tremlett M. Anaesthesia for cleft lip and palate surgery. Curr Anaesth Crit Care. 2004;15:309-16. doi: 10.4103/02591162.123233

4. Johnson CM, Sims C. Awake fiberoptic intubation via a laryngeal mask in an infant with Goldenhar's syndrome. Anaesth Intensive Care. 1994;22:194-7.

5. Kaufmann J, Laschat M, Engelhardt T, Hellmich M, Wappler F. Tracheal intubation with the Bonfils fiberscope in the difficult pediatric airway: a comparison with fiberoptic intubation. Paediatr Anaesth. 2015;25(4):372-8. doi: 10.1111/ pan. 12523

6. Milne AD, Dower AM, Hackmann T. Airway management using the pediatric GlideScope in a child with Goldenhar syndrome and atypical plasma cholinesterase. Paediatr Anaesth. 2007;17(5):484-7.

7. Gooden CK, Pate VA, Lan J, Kavee R. Anesthetic and airway management in a child with Goldenhar syndrome. Paediatr Anaesth. 2005;15(12):1154-66.

8. Madan R, Trikha A, Venkataraman RK, Batra R, Kalia P. Goldenhar's syndrome: an analysis of anaesthetic management. A retrospective study of seventeen cases. Anaesthesia. 1990;45:49-52 


\section{Sažetak \\ ZBRINJAVANJE DIŠNOGA PUTA UZ DIREKTNU LARINGOSKOPIJU U DJETETA S GOLDENHAROVIM SINDROMOM}

\section{B. Vitković i M. Milić}

Goldenharov sindrom je kongenitalni sindrom s općom manifestacijom hemifacijalne mikrosomije zbog nedostatnog sazrijevanja mandibule i anomalijama vratne kralježnice. Svaki anesteziolog treba znati da se u djece s Goldenharovim sindromom predviđa otežano zbrinjavanje dišnoga puta, otežana ventilacija i intubacija. Sindromi se u djece prezentiraju u različitom opsegu. Stoga svako dijete kod kojega je dijagnosticirana malformacija pogotovo dišnoga puta treba detaljno pregledati i odlučiti na koji način pristupiti zbrinjavanju dišnoga puta. U ovom prikazu slučaja dvoipogodišnjeg dječaka zbog zahvata plastike mekoga nepca trebali smo intubirati orotrahealnim putem. Dječak je intubiran direktnom laringoskopijom uz lagani vanjski pritisak na larinks.

Key words: Goldenhar syndrome; Dišni put, zbrinjavanje; Dišni put, opstrukcija; Anesthesia; Palatoplasty 